\title{
Gambaran Pengetahuan Ibu Hamil Tentang Perubahan Anatomi dan Fisiologis yang Terjadi Selama Kehamilan di Puskesmas Cakranegara Mataram
}

\author{
Shohipatul Mawaddah ${ }^{{ }^{*}}$ dan Asri Daniyati ${ }^{1}$ \\ ${ }^{1}$ Jurusan Ilmu Kebidanan, Universitas Nahdlatul Wathan, Mataram, Indonesia \\ *Email : shohip.mut1f4n15@gmail.com
}

\begin{abstract}
Abstrak : Ibu hamil mengalami perubahan anatomi dan fisiologis yang signifikan selama kehamilan dalam rangka memelihara dan mengakomodasi janin yang sedang berkembang. Perubahan ini dimulai setelah pembuahan dan mempengaruhi setiap sistem organ dalam tubuh. Bagi sebagian besar ibu yang mengalami kehamilan tanpa komplikasi, perubahan ini hilang setelah kehamilan dengan efek residual yang minimal. Penting untuk memahami perubahan fisiologis normal yang terjadi pada kehamilan karena ini akan membantu membedakan dari adaptasi yang abnormal. Penelitian ini bertujuan untuk mengetahui dan menganalisis bagaimana gambaran pengetahuan ibu hamil tentang perubahan anatomi dan fisiologi kehamilan. Penelitian ini menggunakan desain deskriptif analitic dengan 30 sampel dari 351 populasi yang terpilih secara acidental sampling. Prosedur analisis data dilakukan dengan menggunakan analisis dengan nilai signifikansi $\alpha=0,05$. Hasil penelitian didapatkan bahwa sebagian besar responden memiliki tingkat Chi square pengetahuan dalam katagori baik (46,7\%), umur responden terbanyak ada pada rentang usia 20-35 tahun (96,7\%), status tidak bekerja $(96,7 \%)$ dan paling banyak responden adalah dengan paritas primigravida $(66,7 \%)$. Uji statistik chi square menunjukkan bahwa hanya tingkat pendidikan yang memiliki nilai $p$ value $=0,012<\alpha=0,05$ yang artinya bahwa ada hubungan yang signifikan antara tingkat pendidikan ibu dengan tingkat pengetahuannya. Sementara untuk umur, pekerjaan dan paritas memiliki nilai $p$ value $>\alpha=0,05$ masing-masing $p=0,554 ; p=0,183$; dan $\mathrm{p}=0,227$ yang artinya bahwa umur, pekerjaan dan paritas tidak memiliki hubungan signifikan dengan tingkat pengetahuannya tentang perubahan anatomi dan fisiologi kehamilan. Dari hasil penelitian diharapkan agar informasi atau sosialisasi terkait perubahan anatomi dan fisiologi ibu hamil selalu diinformasikan kepada ibu hamil agar ibu hamil bisa lebih awal mengenali tanda gejala serta bisa mengatasi ketidaknyamanan yang ditimbulkan oleh perubahan tersebut.
\end{abstract}

Kata kunci : Pengetahuan, Perubahan anatomi dan fisiologi kehamilan

\section{Pendahuluan}

Kehamilan dan perubahannya merupakan proses fisiologis normal yang terjadi pada semua ibu hamil sebagai respons terhadap perkembangan janin. Perubahan ini terjadi sebagai respons terhadap banyak faktor; seperti perubahan hormonal, peningkatan volume darah total, penambahan berat badan, dan peningkatan ukuran janin. Semua faktor ini memiliki dampak fisiologis pada semua sistem wanita hamil diantaranya muskuloskeletal, endokrin, sistem reproduksi, kardiovaskular, pernapasan, sistem pencernaan, dan ginjal. (Kohlhepp LM, 2018)

Perubahan fisiologis terjadi pada kehamilan untuk memelihara janin yang sedang berkembang dan mempersiapkan ibu untuk persalinan. Beberapa dari perubahan ini mempengaruhi nilai biokimia normal sementara yang lain mungkin meniru gejala penyakit medis. Penting untuk membedakan antara perubahan fisiologis normal dan patologi penyakit. (Priya SP, 2016)

Selama kehamilan, ibu hamil mengalami perubahan anatomi dan fisiologis yang signifikan dalam rangka memelihara dan mengakomodasi janin yang sedang berkembang. Perubahan ini dimulai setelah pembuahan dan mempengaruhi setiap sistem organ dalam tubuh. Bagi sebagian besar ibu yang mengalami kehamilan tanpa komplikasi, perubahan ini hilang setelah kehamilan dengan efek residual yang minimal. Penting untuk memahami perubahan fisiologis normal yang terjadi pada kehamilan karena ini akan membantu membedakan dari adaptasi yang abnormal. (Priya SP, 2016)

Perubahan anatomi dan fisiologi dalam kehamilan sering menimbulkan gejala dan komplikasi kehamilan yang dapat berkisar dari ketidaknyamanan ringan dan mengganggu hingga penyakit parah, terkadang mengancam jiwa. Terkadang sulit bagi seorang ibu hamil untuk menentukan gejala mana yang normal dan mana yang tidak. Hal ini tentu dapat mempengaruhi kesehatan ibu atau bayi. Masalah-masalah ini dapat disebabkan oleh atau dapat diperburuk oleh kehamilan. Banyak masalah yang ringan, namun ketika ibu tersebut tidak memahami cara 
mengatasinya, dapat membahayakan ibu atau bayinya. Perlu diingat bahwa ada cara untuk mengelola masalah yang muncul selama kehamilan.

Penjelasan mengenai perubahan selama hamil sangat penting dikarenakan masih banyak ibu atau wanita yang sedang hamil belum mengetahui tentang perubahan-perubahan yang ada pada diri mereka, baik perubahan fisik maupun perubahan psikologis. Maka dari itu peran bidan sangat penting dan dibutuhkan untuk menjelaskan tentang perubahan yang terjadi pada tubuh ibu atau wanita yang sedang hamil dan juga memberikan pelayanan kesehatan bio-psikologis, social dan spiritual tanpa membedakan suku, ras agama, terutama pada ibu hamil yang belum mengetahui tentang perubahan tersebut, sehingga rasa tidaknyaman ataupun antisipasi komplikasi bisa dilakukan secara dini. (Prawirohardjo, 2014)

Dalam penelitian ini, kami mengidentifikasi tujuh pertanyaan utama terkait pengetahuan ibu tentang perubahan anatomi dan fisiologi kehamilan: a) pengetahuan tentang perubahan anatomi fisiologi sistem musculoskeletal; b) pengetahuan tentang perubahan anatomi fisiologi sistem endokrin; c) pengetahuan tentang perubahan anatomi fisiologi sistem reproduksi; d) pengetahuan tentang perubahan anatomi fisiologi sistem kardiovaskular; e) pengetahuan tentang perubahan anatomi fisiologi sistem pernapasan; f) pengetahuan tentang perubahan anatomi fisiologi sistem pencernaan; dan g) pengetahuan tentang perubahan anatomi fisiologi ginjal.

\section{Metode Penelitian}

Desain penelitian yang akan digunakan dalam penelitian ini bersifat deskriptif analitic yaitu peneliti ingin mengambil masalah atau memusatkan perhatian kepada masalah-masalah sebagaimana adanya saat penelitian dilaksanakan selanjutnya hasil penelitian diolah dan dianalisis untuk diambil kesimpulannya. Dari segi waktu penelitian ini bersifat crossectional karena variabel independen berupa karakteristik ibu yang ada dalam penelitian dan pengetahuan ibu terkait peruban anatomi dan fisiologi selama kehamilan sebagai variabel dependen dikumpulkan pada waktu sesaat dan bersamaan. (Notoatmojo, 2012).

Besar sampel dalam penelitian ini adalah sebanyak 30 sampel yang diambil secara acidental sampling dari 351 populasi ibu hamil pada bulan Oktober dan November 2021 yang ada di Wilayah Kerja Puskesmas Cakranegara.

Sumber data yang dikumpulkan merupakan data perimer dengan instrumen berupa kuesioner. Data-data yang dikumpulkan mencakup karakteristik responden yaitu umur ibu, tingkat pendidikan, pekerjaan, dan paritas serta pengetahuan ibu tentang perubahan anatomi dan fisiologi selama hamil yang dikatagorikan menjadi tiga tingkaatan yaitu baik, cukup, dan kurang.
Prosedur analisis data dilakukan dengan menggunakan analisis Chi square dengan nilai signifikansi $\alpha=0,05$.

\section{Hasil dan Pembahasan}

\section{Hasil}

\section{a. Gambaran Karakteristik Responden}

\section{1) Distribusi Responden Berdasarkan Umur}

Tabel 1. Distribusi Responden Berdasarkan Umur di Wilayah Kerja Puskesmas Cakranegara Pada Tahun 2021

\begin{tabular}{|c|l|c|c|}
\hline No & Umur & Jumlah & \% \\
\hline 1 & $<20$ tahun & 1 & $3,3 \%$ \\
\hline 2 & $20-35$ tahun & 29 & $96,7 \%$ \\
\hline 3 & $>35$ tahun & 0 & $0 \%$ \\
\hline \multicolumn{2}{r|}{ Total } & $\mathbf{3 0}$ & $\mathbf{1 0 0} \%$ \\
\hline
\end{tabular}

Tabel 1 diatas menunjukkan bahwa dari 30 responden, lebih banyak responden yang berumur 20-35 tahun sebanyak 29 orang $(96,7 \%)$, hanya 1 orang $(3,3 \%)$ yang berumur $<20$ tahun, dan tidak ada responden yang berumur $>35$ tahun.

\section{2) Distribusi Responden Berdasarkan Tingkat Pendidikan}

Tabel 2. Distribusi Responden Berdasarkan Tingkat Pendidikan di Wilayah Kerja Puskesmas Cakranegara Pada Tahun 2021

\begin{tabular}{|c|c|c|c|}
\hline No & $\begin{array}{c}\text { Tingkat } \\
\text { Pendidikan }\end{array}$ & Jumlah & \% \\
\hline 1 & Tinggi & 1 & $3,3 \%$ \\
\hline 2 & Menengah & 17 & $56,7 \%$ \\
\hline 3 & Dasar & 12 & $40 \%$ \\
\hline & Jumlah & $\mathbf{3 0}$ & $\mathbf{1 0 0} \%$ \\
\hline
\end{tabular}

Tabel 2 diatas menunjukkan bahwa tingkat pendidikan responden yang terbanyak yaitu pendidikan menengah sebanyak 17 orang $(56,7 \%)$, tingkat pendidikan dasar sebanyak 12 orang (40\%) dan tingkat pendidikan yang paling sedikit yaitu tingkat pendidikan tinggi sebanyak lorang $(3,3 \%)$.

\section{3) Distribusi Responden Berdasarkan Status Pekerjaan}

Tabel 3. Distribusi Responden Berdasarkan Status Pekerjaan di Wilayah Kerja Puskesmas Cakranegara Tahun 2021

\begin{tabular}{|c|c|c|c|}
\hline No & Pekerjaan & Jumlah & \% \\
\hline 1 & Bekerja & 1 & $3,3 \%$ \\
\hline 2 & $\begin{array}{c}\text { Tidak } \\
\text { Bekerja }\end{array}$ & 29 & $96,7 \%$ \\
\hline \multicolumn{2}{|c|}{ Total } & $\mathbf{3 0}$ & $\mathbf{1 0 0} \%$ \\
\hline
\end{tabular}


Tabel 3 di atas menunjukkan bahwa dari 30 responden sebagian besar berstatus tidak bekerja yaitu 29 orang dengan presentasi $(96,7 \%)$, dan hanya 1 responden yang bekerja $(3,3 \%)$.

\section{4) Distribusi Responden Berdasarkan Paritas}

Tabel 4. Distribusi Responden berdasarkan Paritas di Wilayah Kerja Puskesmas Cakranegara Tahun 2021

\begin{tabular}{|c|c|c|c|}
\hline No & Paritas & Jumlah & \% \\
\hline 1 & $1 \times$ & 20 & $66,7 \%$ \\
\hline 2 & $2-4 \mathrm{x}$ & 10 & $33,3 \%$ \\
\hline 3 & $\geq 5 \mathrm{x}$ & 0 & $0 \%$ \\
\hline \multicolumn{2}{|c|}{ Total } & $\mathbf{5 0}$ & $\mathbf{1 0 0} \%$ \\
\hline
\end{tabular}

Tabel 4 di atas menunjukkan bahwa lebih banyak responden berparitas primigravida yaitu sebanyak 20 orang $(66,7 \%)$, paritas multigravida sebanyak 10 orang $(33,3 \%)$ dan tidak ada ibu dengan grandemultigravida $(0 \%)$.

\section{5) Distribusi Responden Berdasarkan Tingkat Pengetahuan Tentang Perubahan Fisiologi Selama Kehamilan}

Tabel 5. Distribusi Responden Berdasarkan Tingkat Pengetahuan Ibu Tentang Perubahan Anantomi dan Fisiologi Selama Kehamilan di Wilayah kerja Puskesmas Cakranegara Tahun 2021

\begin{tabular}{|c|c|c|c|}
\hline No & $\begin{array}{c}\text { Tingkat } \\
\text { Pengetahuan } \\
\text { Ibu Hamil }\end{array}$ & Jumlah & $\boldsymbol{\%}$ \\
\hline 1 & Baik & 14 & $46,7 \%$ \\
\hline 2 & Cukup & 9 & $30 \%$ \\
\hline 3 & Kurang & 7 & $23,3 \%$ \\
\hline \multicolumn{2}{|c|}{ Jumlah } & $\mathbf{3 0}$ & $\mathbf{1 0 0 \%}$ \\
\hline
\end{tabular}

Tabel 5 di atas menunjukkan bahwa dari 30 responden sebagian besar memiliki tingkat pengetahuan yang baik tentang perubahan anatomi dan fisiologis yang terjadi pada kehamilan yaitu sebanyak 14 orang $(46,7 \%)$, namun 9 orang memiliki tingkat pengetahuan cukup (30\%) dan 7 orang memiliki pengetahuan yang kurang $(23,3 \%)$.
6) Analisis Bivariat Karakteristik Responden dengan Tingkat Pengetahuan Tentang perubahan fisiologis yang terjadi pada kehamilan

Dari table 6 menunjukkan bahwa berdasarkan karakteristik umur responden, dari 1 responden yang berumur $<20$ tahun tingkat pengetahuan baik tentang perubahan fisiologis kehamilan, dan dari 29 responden berumur 20-35 tahun juga lebih banyak berpengetahuan baik yaitu 13 orang $(44,9 \%)$ namun sekitar 7 orang memiliki pengetahuan kurang $(24,1 \%)$.

Karakteristik tingkat pendidikan menunjukkan dari 12 responden yang berpendidikan dasar lebih banyak yang berpengetahuan kurang sebanyak 6 orang $(50,0 \%)$, dari 17 responden yang berpendidikan menengah lebih banyak yang berpengetahuan baik sebanyak 12 orang $(70,6 \%)$ dan responden yang berpendidikan tinggi memiliki pengetahuan cukup.

Karakteristik pekerjaan menunjukkan dari 1 responden yang bekerja memiliki tingkat pengetahuan kurang, dan dari 29 responden yang tidak bekerja lebih banyak berpengetahuan baik sebanyak 14 orang $(48,3 \%)$.

Karakteritik paritas menunjukkan bahwa dari 20 responden yang berparitas primigravida lebih banyak berpengetahuan baik sebanyak 11 orang $(55,0 \%)$ dan dari 10 responden yang berparitas multigravida lebih banyak berpengetahuan cukup sebanyak 5 orang $(50,0 \%)$.

Uji hubungan dengan Chi square pada tabel 6 menunjukkan bahwa dari semua karakteristik ibu yaitu umur, pendidikan, paritas, dan pekerjaan, hanya pendidikan yang memiliki nilai $\mathrm{p}$ value < $0,05(\mathrm{p}=0,012)$, yang artinya bahwa ada hubungan yang bermakna antara tingkat pendidikan ibu dengan tingkat pengetahuannya tentang perubahan fisiologis

kehamilan. Sedangkan umur $\mathrm{p}=0,554$; paritas $\mathrm{p}=0,227$; dan pekerjaan $\mathrm{p}=0,183$; yang artinya ketiga karakteristik tersebut tidak memiliki hubungan yang bermakna dengan pengetahuan ibu tentang perubahan fisiologis kehamilan. 
Table 6. Hasil Analisis Bivariat Karakteristik Responden dengan Tingkat Pengetahuan Tentang Perubahan Anatomi dan Fisiologis pada Kehamilan di Wilayah kerja Puskesmas Cakranegara Tahun 2021

\begin{tabular}{|c|c|c|c|c|c|}
\hline \multirow[t]{2}{*}{ Variabel } & \multicolumn{3}{|c|}{ Tingkat Pengetahuan } & \multirow{2}{*}{$\begin{array}{l}\text { Total } \\
\mathrm{n}(\%)\end{array}$} & \multirow[t]{2}{*}{$\mathrm{p}$-value } \\
\hline & $\begin{array}{c}\text { Baik } \\
\text { n (\%) }\end{array}$ & $\begin{array}{l}\text { Cukup } \\
\text { n (\%) }\end{array}$ & $\begin{array}{c}\text { Kurang } \\
\mathrm{n}(\%)\end{array}$ & & \\
\hline \multicolumn{6}{|l|}{ Umur } \\
\hline$<20$ tahun & $1(100)$ & $0(0)$ & $0(0)$ & $1(100)$ & 0,554 \\
\hline 20-35 tahun & $13(44,9)$ & $9(31)$ & $7(24,1)$ & $29(100)$ & \\
\hline Total & $14(46,7)$ & $9(30)$ & $7(23,3)$ & $30(100)$ & \\
\hline Pendidikan & & & & & 0,012 \\
\hline Tinggi & $0(0)$ & $1(100)$ & $0(0)$ & $1(100)$ & \\
\hline Menengah & $12(70,6)$ & $4(23,5)$ & $1(5,9)$ & $17(100)$ & \\
\hline Dasar & $2(16,7)$ & $4(33,3)$ & $6(50)$ & $12(100)$ & \\
\hline Total & $14(46,7)$ & $9(30)$ & $7(23,3)$ & $30(100)$ & \\
\hline Pekerjaan & & & & & 0,183 \\
\hline Bekerja & $0(0)$ & $0(0)$ & $1(100)$ & $1(100)$ & \\
\hline Tidak bekerja & $14(48,3)$ & $9(31)$ & $6(20,7)$ & $29(100)$ & \\
\hline Total & $14(46,7)$ & $9(30)$ & $7(23,3)$ & $30(100)$ & \\
\hline Paritas & & & & & 0,227 \\
\hline Primigravida & $11(55)$ & $4(20)$ & $5(25)$ & $20(100)$ & \\
\hline Multigravida & $3(30)$ & $5(50)$ & $2(20)$ & $10(100)$ & \\
\hline Total & $14(46,7)$ & $9(30)$ & $7(23,3)$ & $30(100)$ & \\
\hline
\end{tabular}

\section{Pembahasan}

Dalam penelitian ini, sebagian besar ibu memiliki pengetahuan yang baik tentang perubahan anatomi dan fisiologi yang terjadi pada saat hamil. Memang, hasil menunjukkan bahwa mayoritas ibu tahu bahwa dalam tubuh mereka terjadi perubahan normal yang biasa dialami oleh wanita selama kehamilan, namun ada beberapa ibu yang tidak mengetahui hal tersebut. Temuan ini juga sejalan dengan yang ditemukan dalam penelitian lain.

Dalam sebuah penelitian pada $50 \mathrm{ibu}$ hamil primigravida, hampir $54 \%$ yang memiliki pengetahuan baik tentang perubahan fisiologi selama hamil dan hanya 10 persen yang memiliki pengetahuan yang kurang. (Intan, 2016)

Pengetahuan ibu hamil dipengaruhi beberapa faktor diantaranya umur, pekerjaan, pendidikan, paritas dan sumber informasi. (Notoatmodjo, 2010). Dalam penelitian ini menyatakan bahwa berpengetahuan ibu tentang perubahan anatomi dan fisiologis kehamilan kategori baik paling banyak ditemukan pada kelompok umur 20-35 tahun sebanyak 13 orang (44,9\%). Data ini dapat menunjukkan bahwa ibu hamil di Puskesmas Cakranegara hamil dalam usia reproduksi sehat.

Unicef 2012 memaparkan bahwa masa reproduksi wanita pada dasarnya dibagi dalam tiga periode yakni usia reproduksi muda (15-19 tahun), usia reproduksi sehat (20-35 tahun) dan usia reproduksi tua (36-45 tahun).

Terkait dengan pengetahuan, usia mempengaruhi terhadap daya tangkap dan pola pikir yang dimiliki seseorang. Semakin bertambah usia akan semakin berkembang pula daya tangkap dan pola pikir, sehingga pengetahuan yang diperoleh akan semakin baik. Pada usia produktif, individu akan lebih berperan aktif dalam masyarakat dan kehidupan sosial serta lebih banyak melakukan persiapan demi suksesnya upaya meyesuiakan diri menuju usia tua, selain itu usia produktif akan lebih banyak menggunakan banyak waktu untuk membaca. Kemampuan intelektualnya, pemecahan masalah, dan kemampuan verbal tidak ada penurunan pada usia ini. Beberapa teori berpendapat ternyata IQ seseorang akan menurun cukup cepat sejalan dengan bertambahnya usia hal ini disebabkan karena kemunduran baik fisik maupun mental. (Sunaryo, 2016)

Namun, hasil analisis chi square menunjukkan bahwa variabel umur memiliki hubungan yang tidak signifikan $(\mathrm{p}=0,554)$ terkait dengan pengetahuan ibu tentang perubahan anatomi dan fisiologi selama kehamilan. Responden yang memiliki umur lebih tua sama-sama memiliki tingkat pengetahuan yang baik dengan ibu yang memiliki usia lebih muda. Dengan majunya teknologi zaman ini, memudahkan siapa saja baik usia dini atau lebih dewasa bisa mengakses segala informasi termasuk informasi kesehatan.

Selain umur, faktor pendidikan juga mempengaruhi tingkat pengetahuan seseorang. Ibu dengan tingkat pendidikan sekolah dasar atau lebih rendah secara signifikan lebih kecil kemungkinannya untuk mengetahui hal-hal yang berkaitan dengan perubahan anatomi dan fisiologi selama kehamilan dibandingkan wanita dengan gelar sarjana atau lulusan menengah $(\mathrm{p}=.0,012)$.

Menurut Manuaba (2013), salah satu faktor yang banyak memberi pengetahuan pada manusia adalah pendidikan, baik itu pendidikan formal maupun non formal. Tidak adanya pendidikan pada seseorang dapat menyebabkan kurangnya pengetahuan. Demikian juga dengan ibu hamil yang tidak megalami atau memperoleh pendidikan tentu 
saja akan berakibat pada kurangnya pengetahuan tentang hal-hal yang berkaitan dengan kehamilannya.

Hal ini juga sejalan dengan penelitian yang berhubungan dengan tingkat pendidikan dalam mempengaruhi pengetahuan ibu tentang faktor resiko kehamilan, bahwa ada hubungan signifikan antara wanita dengan tingkat pendidikan sarjana terhadap pengetahuan yang lebih baik tentang faktor risiko kehamilan dibandingkan wanita dengan gelar pendidikan sekolah lebih rendah (OR $=0,64 ; 95 \% \mathrm{CI}=0,43-0,95)$. (Esposito et al, 2015). Sejalan pula dengan penelitian Borodulin et al (2011), menunjukkan bahwa pengetahuan tentang latihan fisik pada kehamilan secara signifikan lebih tinggi terjadi pada wanita dengan tingkat sekolah yang lebih baik.

Dalam katagori pekerjaan, diketahui bahwa pekerjaan adalah suatu kegiatan untuk menafkahi diri dan keluarganya, (Nursalam, 2008). Masalah yang sering muncul pada wanita hamil salah satunya adalah kelelahan. Kelelahan tersebut meliputi kelelahan fisik terutama disebabkan oleh pekerjaan rutin sehari-hari, seperti pekerjaan di kantor atau dirumah sebagai ibu rumah tangga, dan aktivitas-aktivitas lainnya. Jenis pekerjaan responden mengarah pada tingkat aktivitas seharihari, hal ini dapat mempengaruhi kondisi fisik mental serta kesempatan untuk mempertahankan kebutuhan dan kesehatan ibu.

Dari penelitian yang telah dilakukan, terdapat paling banyak responden yang tidak bekerja yaitu 29 responden $(96,7 \%)$, dan 1 responden yang bekerja $(3,4)$.

Dari hasil penelitian tersebut diatas dapat dilihat bahwa banyaknya responden yang tidak bekerja memiliki pengetahuan yang baik atau cukup tentang perubahan anatomi dan fisiologi selama hamil. Berbeda dengan ibu yang bekerja yang memiliki pengetahuan yang kurang. Uji anailisis chi square juga menunjukkan hubungan yang tidak signifikan $(\mathrm{p}=0,183)$ yang artinya tidak ada pengaruh status pekerjaan dengan tingkat pengetahuan ibu.

Hal ini menunjukkan bahwa baik ibu bekerja maupun tidak bekerja sama-sama memiliki kesempatan untuk menggali segala informasi terkait kesehatan kehamilan. Jadi, meskipun ibu tidak bekerja maka dia memiliki kesempatan yang sama dengan ibu yang bekerja untuk memiliki pengetahuan dan pengalaman yang banyak dalam kehidupan sehari-hari. Bertentangan dengan teori yang dinyatakan oleh Sujiyono dkk (2004) yang mengatakan bahwa seseorang yang bekerja memiliki pengetahuan lebih luas dari pada seseorang yang tidak bekerja karena dengan bekerja seseorang memiliki banyak informasi yang akurat dari lingkungan sekitarnya.

Penelitian serupa juga menunjukkan bahwa tidak ada hubungan yang signifikan antara pekerjaan seorang wanita hamil dengan pengetahuan ibu tentang faktor resiko kehamilan $(\mathrm{OR}=0,68 ; 95 \% \mathrm{CI}=0,42-1,11)$
Hasil penelitian juga menggambarkan bahwa dari 20 responden dengan paritas primigravida paling banyak memiliki tingkat pengetahuan baik (55\%), sedangkan paritas dengan multigravida memiliki tingkat pengetahuan yang cukup (50\%). Hasil uji statistic menunjukkan bahwa tidak ada hubungan signifikan antara paritas dengan tingkat pengetahuan ibu $(\mathrm{p}=0,227)$. Yang artinya bahwa meskipun ibu dengan paritas pertama kali hamil bukan berarti memiliki pengetahuan yang tidak lebih baik dibandingkan dengan ibu yang sudah pernah memiliki pengalaman hamil. Sejalan dengan penelitian Esposito et al (2015) bahwa tidak ada hubungan signifikan antara paraitas wanita dengan tingkat pendidikan $(\mathrm{OR}=0,38 ; 95 \% \mathrm{CI}=0,87-$ $2,43)$.

\section{Kesimpulan}

Tingkat pengetahuan ibu tentang perubahan anatomi dan fisiologi kehamilan ada dalam katagori baik di mana umur, jumlah anak, dan pekerjaan ibu tidak memiliki hubungan yang signifikan dengan tingkat pengetahuan. Sementara tingkat pendidikan ibu memiliki hubungan yang signifikan dengan pengetahuan ibu.

\section{Daftar Pustaka}

Borodulin K, Evenson K, Wen F, Herring A, Physical Activity Patterns during Pregnancy. Medicine \& Science in Sports \& Exercise journal. 2012. 40 (11): 1901-1908

Esposito G, Ambrosio R, Napolitano F, Giuseppe GD. 2015. Women's Knowledge, Attitudes and Behavior about Maternal Risk Factors in Pregnancy. PLoS ONE journal. 10 (12): e0145873

Intan N, Restuastuti T, Pangaribuan ER. 2016. Gambaran Pengetahuan Dan Sikap Ibu Hamil Primigravida Terhadap Perubahan Fisiologis Tubuh Yang Terjadi Selama Masa Kehamilan Di Wilayah Kerja Puskesmas Rejosari Pekanbaru. Jom FK. 3 (2): 1-9

Kohlhepp LM, Hollerich G, Hofman K, Rehm M, Louwen F, Zacharowski F, Weber CF. 2018. Physiological changes during pregnancy. Ueurope PMC. 67(5):383-396

Manuaba, Ida Bagus Gede. 2013. Ilmu Kebidanan, Penyakit Kandungan dan KB. Jakarta: EGC

Notoatmodjo, S. 2010. Pendidikan dan Perilaku Kesehatan. Jakarta : Rineka Cipta

Notoatmodjo, S. 2012. Metodologi Penelitian Kesehatan. Jakarta: Rineka Cipta

Nursalam \& Efendi, Ferri. 2008. Pendidikan Dalam Keperawatan. Jakarta: Salemba Medika.

Prawirohardjo S. 2014. Ilmu Kebidanan. Jakarta: Yayasan Bina Sarwono Prawirohardjo

Priya SP, Catherine NP, Heli T, Alexandre M. 2016. Physiological changes in pregnancy. Cardiovascular Journal Of Africa. 27 (2): 89-94 
Sujiono dkk. 2004 Metode Pengembangan Kognitif: Jakarta. Universitas Terbuka.

Sunaryo, Wijayanti, Rahayu. (2016). Asuhan Keperawatan Gerontik. Yogyakarta : CV ANDI OFFSET.

Unicef. 2012. Pedoman Hidup Sehat. Jakarta: Unicef. 